\title{
Analysis of Accessibility to Family Health Centers in Antalya Using GIS
}

\author{
Orhun Soydan ${ }^{1, a, *}$ \\ ${ }^{1}$ Landscape Architecture Department, Faculty of Architecture, Niğde Ömer Halisdemir University, 51240 Niğde, Turkey
} ${ }^{*}$ Corresponding author

\begin{tabular}{|c|c|}
\hline A R T I C L E I N F O & A B S T R A C T \\
\hline $\begin{array}{l}\text { "This study was presented as an online } \\
\text { presentation at the } 2^{\text {nd }} \text { International } \\
\text { Journal of Agriculture - Food Science } \\
\text { and Technology (TURJAF 2021) } \\
\text { Gazimağusa/Cyprus } \\
\text { Research Article }\end{array}$ & $\begin{array}{l}\text { Family health centers in Turkey started to be implemented for the first time in Düzce in } 2004 \text { years } \\
\text { within the scope of Law No. } 5258 \text {. While determining the physical conditions of the places where } \\
\text { family health centers are built, the first item in the regulation is that the building should be easily } \\
\text { accessible. This situation shows the importance of the subject in terms of accessibility. While } \\
\text { determining the features of the places where FHCs will be made, environmental characteristics are } \\
\text { also taken into consideration. Environmental features are effective in determining the FHCs location } \\
\text { in different ways. These impacts are divided into two groups: the physical features that pavements, } \\
\text { roads and parks can include, and the social, cultural and institutional features of neighborhoods that } \\
\text { include local social ties and collective activities. From this point of view, the importance of the } \\
\text { location of family health centers relative to roads and houses is understood. The aim of this study } \\
\text { is to examine the accessibility of Family Health Centers in Konyaalt1, Antalya, on a neighborhood } \\
\text { basis using Geographic Information Systems. Konyaalt has } 21 \text { Family Health Centers. As a result } \\
\text { of the analyses, it was determined that most of the neighborhoods had problems in terms of } \\
\text { accessibility, while a very few of them did not experience problems in terms of accessibility. In } \\
\text { terms of the total number of buildings, the ratio of buildings that are } 500 \text { meters walking distance } \\
\text { from any family health center by using highways is } 35.56 \% \text {. With these rates, } 3,634 \text { of the } 10,2018 \\
\text { buildings remain within the limits of the regulation. Finally; suggestions were made to increase } \\
\text { accessibility to these areas. }\end{array}$ \\
\hline
\end{tabular}

\section{Introduction}

Although population is an important factor in drawing city boundaries, the pressure on settlements has increased as a result of the rapid increase the population living in cities. Although supporting migration from the city to the countryside seems like a solution to prevent the increasing population pressure, it is obvious that a significant part of the urban population will not return to the rural areas. The population in cities is also increasing due to rapid population growth. Developed countries started to produce different formulas for the solution these problem towards the end of the $20^{\text {th }}$ century. The most important of these solutions is the "smart city concept". Accordingly, in order to benefit more effectively from information and communication technologies, there is a growing need for human and environment-centered smart city systems, where existing resources can be used as efficiently as possible.

Smart city offers data-based solutions and systems that can be integrated into life with high technology (Akdamar,
2017). According to Yomralığlu (2005), urban information system is the services such as collecting, storing and sharing the information obtained by the institutions, which includes all the phenomena that are effective in city life such as infrastructure, superstructure, security, transportation, education and tourism (Deniz et al., 2018).

While smart cities create a new paradigm in urbanism studies, urban planning has started to be done in the same focus. Due to its increasing importance, smart cities are getting popular day by day in the construction of international policies and scientific literature (Albino et al., 2015; Deniz, 2018). One of the most important components of smart cities is shown as smart transportation (Figure 1).

The necessary spatial infrastructure must be built in order for the vehicles connected to automation and communicating with each other to move smoothly. The concept of spatial infrastructure does not only consist of the correct equipment of the roads, traffic signs. 
The smart city and smart transportation will be perfect only with a properly planned city. As Çelikyay (2013) emphasized, transportation problem can be the most common problem in terms of smart cities. In order to prevent this, it is necessary to provide the smoothest access, taking into account the needs of both vehicles and pedestrians (Deniz, 2018). Health infrastructure and accessibility is paramount to every community since it has the facility to influence the quality-of-care individuals are able to receive. When it comes to infrastructure, it is paramount to determine the underlying health conditions the local population faces and whether the accommodations provided are adequate in accommodating the population (Kwan and Trisha, 2021).

In terms of information technologies, Geographic Information Systems (GIS) is one of the rapidly developing technologies.In the current century, technological developments and their application in different areas are also reflected in urban designs. In cities planned with a new generation approach, innovation, technology use and GISbased analyzes in city administration come to the fore. Geographical Information Systems, which have been used for 15-20 years in our country and have become increasingly widespread in recent years, are suitable for use in smart city applications. At the beginning of these usage areas, certain structures, institutions, etc., which are important during planning. location determination. As in this study, a structure, institution, hardware, etc. A suitable place can be determined by considering only the accessibility criteria, or a suitable place can be selected by determining a few criteria with the geographic information system and taking all of them into account.

The aim of the study is to reveal the extent to which 21 family health centers in the city can be accessed from the residences in the neighborhoods that form the center of Konyaalt1, how many of the people living in these residences can reach the family health centers in an appropriate way, and how the locations of these family health centers comply with the relevant regulations. The study includes the application of the network analysis method, which has been applied by different researchers in various studies (Melo et al., 2015; Yeşil and Yeşil, 2017; Deniz et al., 2018; Deniz et al., 2020; Deniz et al., 2021; Mendonça et al., 2021) in the past. The fact that access to health services within the borders of Antalya is revealed for the first time in terms of population and residences with network analysis constitutes the originality of the study.

\section{Materials and Method}

The Family Healty Center of Konyaaltı District in Antalya were examined (Figure 1). Konyaalt1 is located between $30^{\circ} 42^{\prime} 14.5584^{\prime \prime}$ east longitude and 36 53'5.2944" north latitude. Antalya is surrounded by the Mediterranean in the south, Muğla in the west, Burdur and Isparta in the north, Konya in the northeast, Karaman and Mersin in the east. Konyaaltı district is the $5^{\text {th }}$ largest district of Antalya and has a great tourism potential. First of all, the necessary data were obtained from the relevant institutions. The data collected for use in this study were made suitable for analysis by the researchers or the relevant institution statistics were directly included in the study.

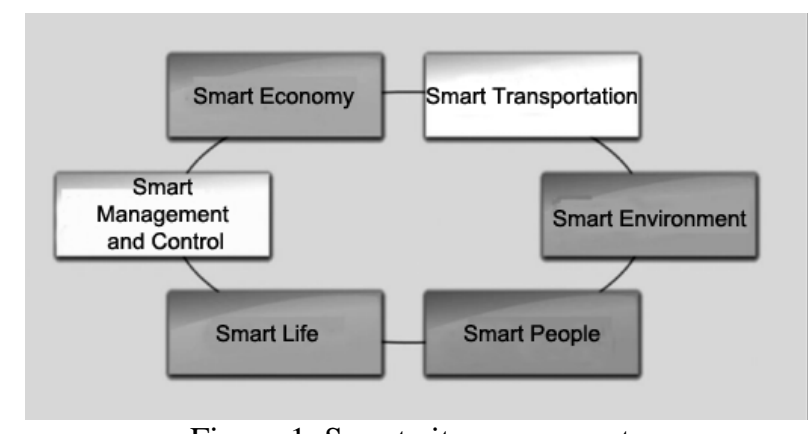

Figure 1. Smart city components (Çelikyay, 2013; Deniz, 2018)
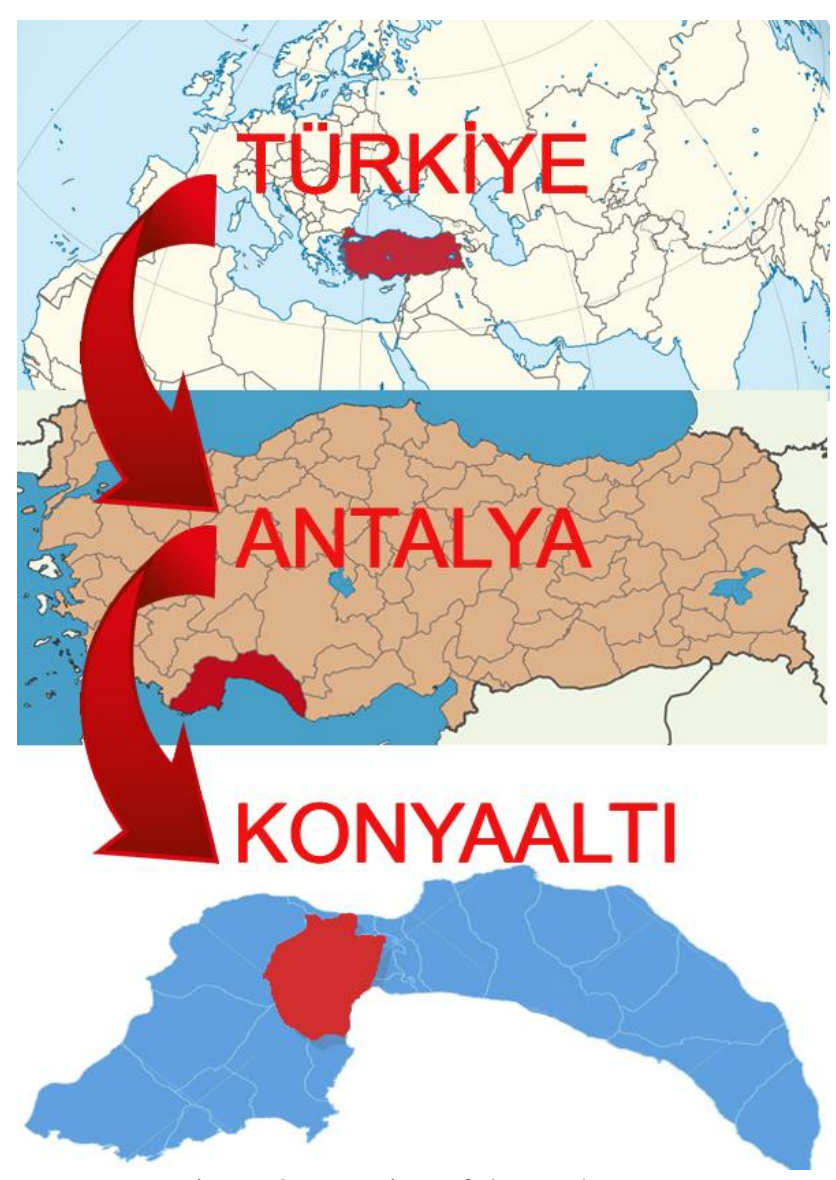

Figure 2. Location of the study area

The data sets used in the study consist of the addresses of the Family Health Centers affiliated to the Ministry of Health within the borders of Konyaalt district and the vector data set created through these addresses, the digital transportation network, the numerical (vector) data of the houses in Konyaalt1, the population data according to the neighborhoods in the study area. Another data of the study is the road network of the city. The correctness of the road network is the most important factor affecting the accuracy of the analysis results. The road network used in the study was created by using the zoning plan and OpenStreetMap (OpenStreetMap, 2021) open data from the relevant municipality. Network analysis, which is an example of spatial analysis, has been applied and spatial accessibility has been revealed. The ArcMap 10.8 software was used in the analysis. 
The population data with age range according to the neighborhoods of the city used in the ratio of the accessibility rates obtained as a result of the applied network analysis to the population was obtained from the Turkish Statistical Institute. While applying the accessibility analysis, the locations of the houses scattered in the neighborhoods and the number of buildings in each neighborhood were taken into account.Since the number of individuals residing in the residences in the city cannot be obtained from TUIK (Turkish Statistical Institute), Provincial Population Directorate or District Population Directorate, the population living in a neighborhood is divided by the number of buildings in that neighborhood and it is assumed that the population is equally distributed to each building. In this respect, whatever access level the location of the building is, the population in that neighborhood and location is accepted as having access at the same rate. It has been observed that this approach has been used by different researchers in the past (Güray and Kemeç, 2016; Deniz, 2018; Deniz et al., 2018; Yasak, 2020; Duman and İrcan, 2020; Deniz et al., 2020).

In terms of accessibility analysis, the 'Multiple Ring Buffer' extension in Arc-GIS 10.8 software was applied in the study. The accessible areas were determined in the light of the regulations followed as: Spatial Plans Building Code, Chapter Four, The Rules Regarding The Building of Spatial Plans, The Walking distances Article: 12 Item 2 "In the construction plans; considering following distances; playground, children's park, outdoor district sports field, primary care clinic, kindergarten, pre-school, and primary school functions about 500 metres, secondary schools about 1,000 metres and high schools about 2,500 metres, can be planned as service influence area as a pedestrian." (Ministry of Environment and Urbanization, 2014). 500 meters distance value in the law was taken as reference in this study. However, , analyzes were also applied as an alternative distance value of 1000 meters. In other studies (Deniz, 2018; Deniz et al., 2020) were made at a distance of 100 meters as an alternative.

\section{Results and Discussion}

Konyaaltı district has 39 neighborhoods, and its total population is 189,078 in 2020 (Figure 3).

While Hurma was the neighborhood with the highest population with 28,109 , Gökdere was the neighborhood with the least population with 86 (Table 1).

There are 21 family health centers in Konyaaltı. Most of these health areas are located in the central neighborhoods of the district, and they are almost nonexistent in rural areas (Figure 4).

Network analysis was applied to 21 family health centers, and problems were identified in terms of accessibility.

When the results of the network analysis of the locations of the FHCs are examined, it has been determined that the impact areas of the FHCs overlap in some areas (Figure 5).

It is seen that there are problems in terms of accessibility, except for a few neighborhoods, within 500 meters of the legal directive. In terms of the total number of buildings, the ratio of buildings that are 500 meters walking distance from any family health center by using highways is $35.56 \%$. With these rates, 3,634 of the 10,2018 buildings remain within the limits of the regulation. Among these neighborhoods, the access rate in Öğretmenevleri is $97.8 \%$, Akkuyu $92.2 \%$ and Toros $91.5 \%$ (Table 2).

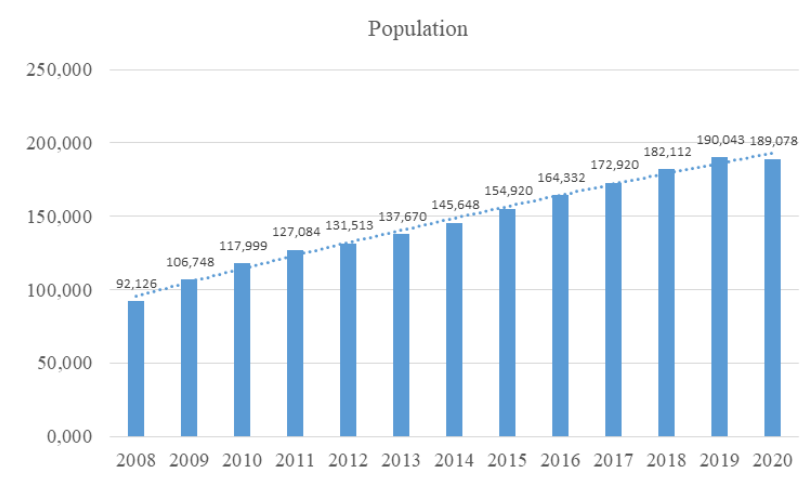

Figure 3. Population changes of Konyaaltı (TUİK, 2020)

Table 1. Properties of the Konyaaltı neighborhoods*

\begin{tabular}{|c|c|c|}
\hline No & Neighborhood & Population \\
\hline 1 & Hurma & 28,109 \\
\hline 2 & Liman & 18,680 \\
\hline 3 & Uncalı & 18,013 \\
\hline 4 & Siteler & 16,771 \\
\hline 5 & Pınarbaşı & 14,916 \\
\hline 6 & Gürsu & 14,355 \\
\hline 7 & Mollayusuf & 10,548 \\
\hline 8 & Toros & 9,691 \\
\hline 9 & Öğretmenevleri & 8,921 \\
\hline 10 & Altınkum & 8,503 \\
\hline 11 & Arapsuyu & 6,969 \\
\hline 12 & Uluç & 6,912 \\
\hline 13 & Sarısu & 6,750 \\
\hline 14 & Akkuyu & 3,477 \\
\hline 15 & Kuşkavağı & 3,169 \\
\hline 16 & Aş.Karaman & 1,540 \\
\hline 17 & Bahtılı & 1,263 \\
\hline 18 & Çakırlar & 1,257 \\
\hline 19 & Aydınlık & 979 \\
\hline 20 & Karatepe & 892 \\
\hline 21 & Doyran & 648 \\
\hline 22 & Hisarçandır & 648 \\
\hline 23 & Kir & 589 \\
\hline 24 & Hacisekililer & 552 \\
\hline 25 & Geyikbayırı & 542 \\
\hline 26 & Dağ & 537 \\
\hline 27 & Çamlıbel & 495 \\
\hline 28 & Gökçam & 462 \\
\hline 29 & Akdamlar & 419 \\
\hline 30 & Yarbaşçandır & 410 \\
\hline 31 & Suiçeçek & 388 \\
\hline 32 & Yeni & 358 \\
\hline 33 & Çağlarca & 283 \\
\hline 34 & Zümrüt & 262 \\
\hline 35 & Demircilik & 226 \\
\hline 36 & Üçoluk & 211 \\
\hline 37 & Kuruçay & 130 \\
\hline 38 & Çitdibi & 117 \\
\hline 39 & Gökdere & 86 \\
\hline
\end{tabular}

*(TUíK, 2020) 


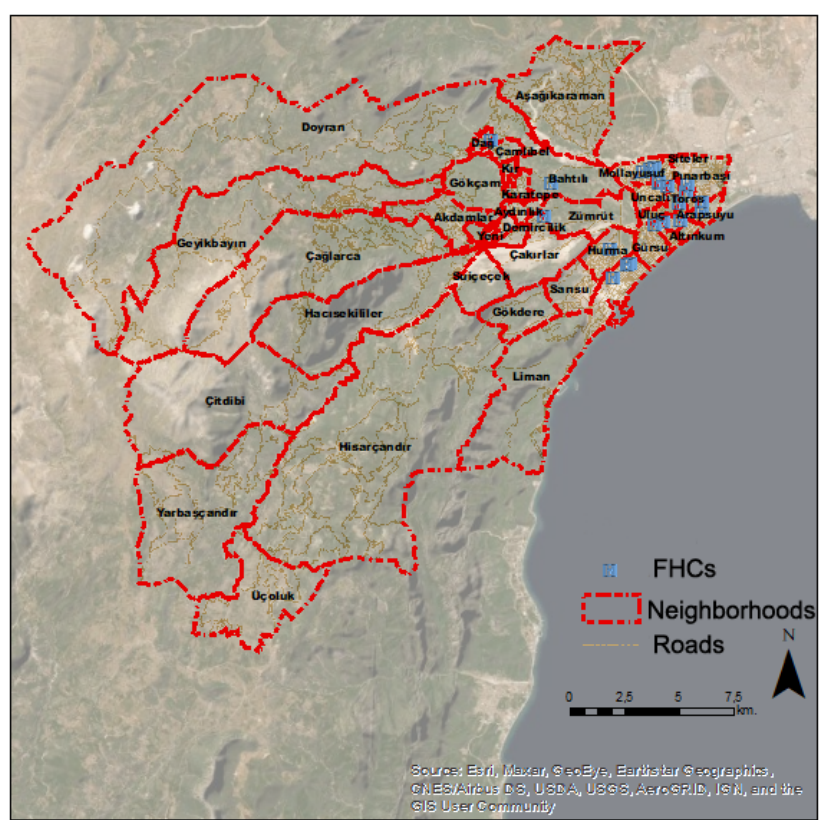

Figure 4. FHCs locations in Konyaalt1

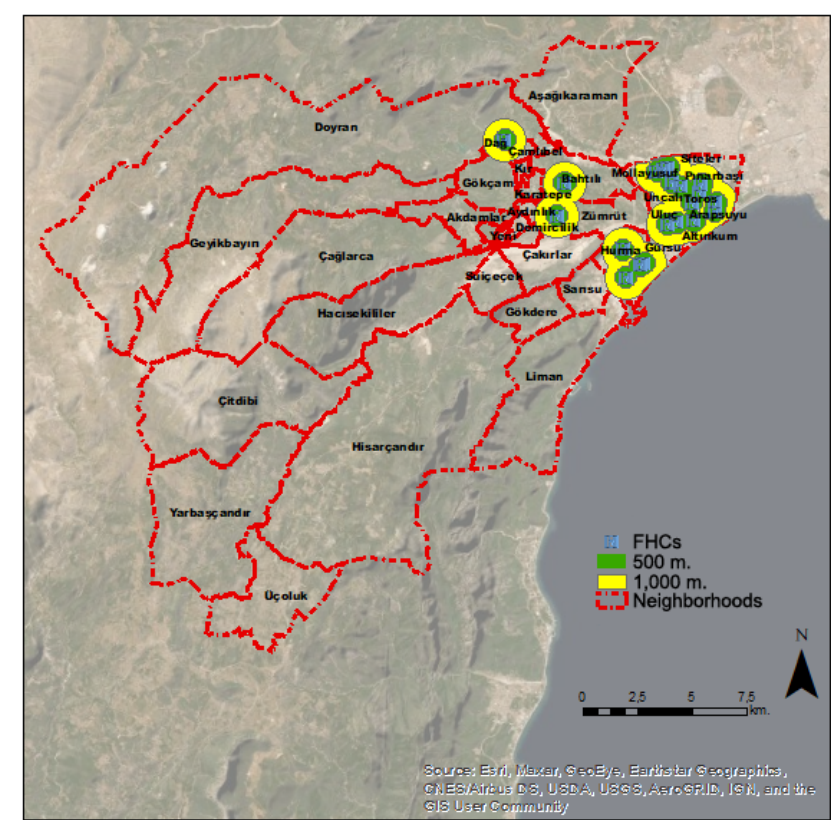

Figure 5. Distance analysis to FHCs

Table 2. Total Building, Suitable Accessible Buildings and Accessible Population by Neighborhoods

\begin{tabular}{|c|c|c|c|c|c|c|c|c|c|c|}
\hline \multirow[t]{2}{*}{$\mathrm{N}$} & \multirow[t]{2}{*}{ NB } & \multicolumn{2}{|c|}{ FHCs } & \multicolumn{2}{|c|}{ Accessible Rate } & \multirow[t]{2}{*}{$\mathrm{P}$} & \multicolumn{2}{|c|}{$\begin{array}{l}\text { Accessibility } \\
\text { Population }\end{array}$} & \multicolumn{2}{|c|}{$\begin{array}{c}\text { Accessibility Population } \\
\text { Rate }\end{array}$} \\
\hline & & $0-500$ & $500-1000$ & $0-500(\%)$ & $500-1000(\%)$ & & $0-500$ & $500-1000$ & $0-500(\%)$ & $500-1000(\%)$ \\
\hline Akdamlar & 181 & 0 & 0 & 0.0 & 0.0 & 419 & 0 & 0 & 0.0 & 0.0 \\
\hline Akkuyu & 116 & 107 & 9 & 92.2 & 7.8 & 3,477 & 3,207 & 270 & 92.2 & 7.8 \\
\hline Altınkum & 634 & 325 & 301 & 51.3 & 47.5 & 8,503 & 4,359 & 4,037 & 51.3 & 47.5 \\
\hline Arapsuyu & 479 & 397 & 82 & 82.9 & 17.1 & 6,969 & 5,776 & 1,193 & 82.9 & 17.1 \\
\hline Așağıkaraman & 422 & 0 & 0 & 0.0 & 0.0 & 1,540 & 0 & 0 & 0.0 & 0.0 \\
\hline Aydınlık & 73 & 0 & 29 & 0.0 & 39.7 & 979 & 0 & 389 & 0.0 & 39.7 \\
\hline Bahtılı & 75 & 16 & 18 & 21.3 & 24.0 & 1,263 & 269 & 303 & 21.3 & 24.0 \\
\hline Cağlarca & 338 & 0 & 0 & 0.0 & 0.0 & 283 & 0 & 0 & 0.0 & 0.0 \\
\hline Cakırlar & 63 & 15 & 41 & 23.8 & 65.1 & 1,257 & 299 & 818 & 23.8 & 65.1 \\
\hline Camlibel & 172 & 21 & 70 & 12.2 & 40.7 & 495 & 60 & 201 & 12.2 & 40.7 \\
\hline Citdibi & 11 & 0 & 0 & 0.0 & 0.0 & 117 & 0 & 0 & 0.0 & 0.0 \\
\hline Dağ & 55 & 17 & 36 & 30.9 & 65.5 & 537 & 166 & 351 & 30.9 & 65.5 \\
\hline Demircilik & 56 & 0 & 0 & 0.0 & 0.0 & 226 & 0 & 0 & 0.0 & 0.0 \\
\hline Doyran & 313 & 23 & 76 & 7.3 & 24.3 & 648 & 48 & 157 & 7.3 & 24.3 \\
\hline Geyikbayırı & 505 & 0 & 0 & 0.0 & 0.0 & 542 & 0 & 0 & 0.0 & 0.0 \\
\hline Gökçam & 142 & 0 & 9 & 0.0 & 6.3 & 462 & 0 & 29 & 0.0 & 6.3 \\
\hline Gökdere & 12 & 0 & 0 & 0.0 & 0.0 & 86 & 0 & 0 & 0.0 & 0.0 \\
\hline Gürsu & 691 & 169 & 355 & 24.5 & 51.4 & 14,355 & 3,511 & 7,375 & 24.5 & 51.4 \\
\hline Hacisekililer & 132 & 0 & 0 & 0.0 & 0.0 & 552 & 0 & 0 & 0.0 & 0.0 \\
\hline Hisarçandır & 192 & 0 & 0 & 0.0 & 0.0 & 648 & 0 & 0 & 0.0 & 0.0 \\
\hline Hurma & 980 & 419 & 521 & 42.8 & 53.2 & 28,109 & 12,018 & 14,944 & 42.8 & 53.2 \\
\hline Karatepe & 141 & 0 & 0 & 0.0 & 0.0 & 892 & 0 & 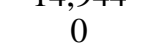 & 0.0 & 0.0 \\
\hline Kir & 214 & 0 & 1 & 0.0 & 0.5 & 589 & 0 & 3 & 0.0 & 0.5 \\
\hline Kuruçay & 26 & 6 & 20 & 23.1 & 76.9 & 130 & 30 & 100 & 23.1 & 76.9 \\
\hline Kușkavağ & 161 & 97 & 64 & 60.2 & 39.8 & 3,169 & 1,909 & 1,260 & 60.2 & 39.8 \\
\hline Liman & 990 & 608 & 280 & 61.4 & 28.3 & 18,680 & 11,472 & 5,283 & 61.4 & 28.3 \\
\hline Mollayusuf & 509 & 304 & 173 & 59.7 & 34.0 & 10,548 & 6,300 & 3,585 & 59.7 & 34.0 \\
\hline Öğretmenevleri & 275 & 269 & 6 & 97.8 & 2.2 & 8,921 & 8,726 & 195 & 97.8 & 2.2 \\
\hline Pinarbașı & 462 & 207 & 142 & 44.8 & 30.7 & 14,916 & 6,683 & 4,585 & 44.8 & 30.7 \\
\hline Sarısu & 188 & 0 & 4 & 0.0 & 2.1 & 6,750 & 0 & 144 & 0.0 & 2.1 \\
\hline Siteler & 218 & 153 & 65 & 70.2 & 29.8 & 16,771 & 11,770 & 5,001 & 70.2 & 29.8 \\
\hline Suiçeçek & 113 & 0 & 14 & 0.0 & 12.4 & 388 & 0 & 48 & 0.0 & 12.4 \\
\hline Toros & 260 & 238 & 22 & 91.5 & 8.5 & 9,691 & 8,871 & 820 & 91.5 & 8.5 \\
\hline Uluc & 255 & 149 & 106 & 58.4 & 41.6 & 6,912 & 4,039 & 2,873 & 58.4 & 41.6 \\
\hline Uncalı & 509 & 91 & 345 & 17.9 & 67.8 & 18,013 & 3,220 & 12,209 & 17.9 & 67.8 \\
\hline Ücoluk & 49 & 0 & 0 & 0.0 & 0.0 & 211 & 0 & 0 & 0.0 & 0.0 \\
\hline Yarbaşçandır & 63 & 0 & 0 & 0.0 & 0.0 & 410 & 0 & 0 & 0.0 & 0.0 \\
\hline Yeni & 115 & 0 & 0 & 0.0 & 0.0 & 358 & 0 & 0 & 0.0 & 0.0 \\
\hline Zümrüt & 28 & 3 & 11 & 10.7 & 39.3 & 262 & 28 & 103 & 10.7 & 39.3 \\
\hline
\end{tabular}

$\mathrm{N}$ : Neighbourhood, NB: Number of Buildings, P: Population 
Akdamlar, Aşağıkaraman, Çağlarça, Çitdibi, Demircilik, Geyikbayırı, Gökdere, Hacısekililer, Hisarçandır, Karatepe, Üçoluk, Yarbaşçandır and Yeni $(0.00 \%)$ neighborhoods are among the neighborhoods where accessibility problems due to their location preferences.

In addition to these 13 neighborhoods, the access rate in 11 neighborhoods is below $50 \%$. While the rate of access to FHCs at 500 meters is $35.56 \%$, this rate is $27.40 \%$ at 1,000 meters. The rate of accessibility of the buildings in 6 neighborhoods and the population living in these buildings to FHCs within 1,000 $\mathrm{m}$ is over $50 \%$. These rates show that the problematic buildings seen at a distance of 500 meters in terms of accessibility continues at 1,000 meters. The total of the population aged 0-4 and over 65 , who may have problems in walking to family health centers in the research area, is 26,660 (Figure 6).

However, considering that the distance determined for the school-going distances of secondary school children is 500 meters in the regulation, it comes to mind that the same distance can be used for FHCs. In such a case, in the city where 22,621 people between the ages of 0-9 and 16,740 people over the age of 65 live, 39,361 people are expected to be evaluated within 500 meters of walking distance to access FHCs (Table 3).

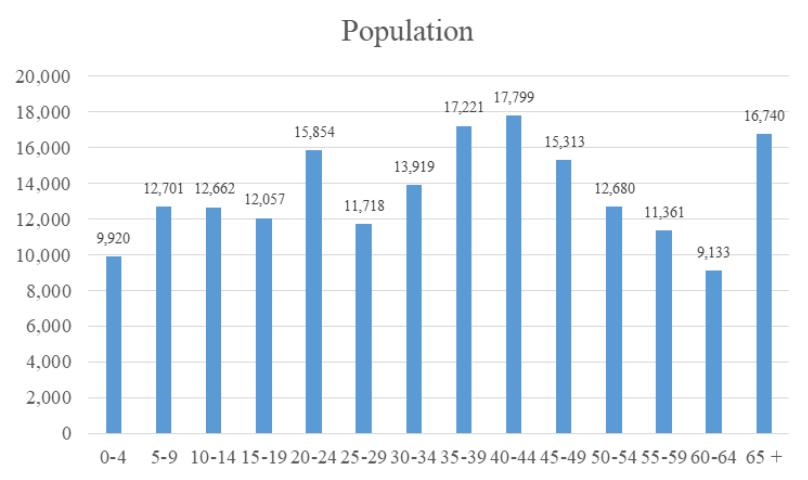

Figure 6. Distribution of Population by Age Groups

(TUIK, 2020)

In Konyaaltı district, especially Hurma ( 5,852 people), Liman (3,889 people), Uncalı (3,750 people), Siteler $(3,491)$, and Pınarbaş1 $(3,105)$ are the neighborhoods where individuals in these age groups live the most. 39,361 people in this age group, 20,087 live in the aforementioned neighborhoods. It is seen that the rate of those living in these neighborhoods within the two age groups constitutes $51.03 \%$ of the total of the groups.

When the accessibility rates of Hurma (42.8\%), Liman (61.4\%), Uncalı (17.9\%), Siteler (70.2\%) and Pınarbaşı (44.8\%) neighborhoods are considered, the average value is \% values close to 25.25 stand out. However, considering that approximately $75 \%$ of the population is likely to encounter access problems in the analysis based on 500 meters, it is seen that there is a significant problem. The fact that FHCs are outside the walking distance creates a problem for the younger ones and the elderly population who have to go to the doctor alone.

\section{Conclusion}

Health Geography is an increasingly important field of study in the context of human and space interaction. Health geography studies in Turkey, on the other hand, have gained attention in recent years by gaining a different dimension with the examination of the subject in terms of accessibility to health institutions. Health problems, pandemic processes, etc. that are experienced or likely to be experienced in the world and in Turkey. Considering this, it is clear that the analysis of the location choices of health centers is a necessity today. However, accessibility to health services can be evaluated within the scope of basic needs beyond the importance of spatiality. This study contributes to the planning of meeting this basic need in terms of its findings (Deniz et al., 2020).

When the spatial analysis findings made as a result of the research are examined, it is seen that there are problems in Konyaalt 1 regarding access to family health centers. The distribution and sufficient number of family health centers in and around the district center made access to these regions easy. However, there are problems in terms of access in areas outside the central districts. The biggest problem in these neighborhoods is that the family centers are not in accessible areas, or there is no FHCs in the neighborhood. It has been observed that in Konyaalt1, FHCs are not equally distributed throughout the city, and as a result, access to FHCs is experienced from a significant part of the buildings in the research area.

The number of buildings within the 1000-meter walking distance, which is handled differently from the regulation, has decreased compared to the 500-meter walking distance. This shows that FHCs collect in certain areas. It is seen that 3,634 out of 189,078 people living in Konyaaltı remain within the limits that comply with the distance in the regulation. However, care should be taken to keep the population aged $0-14$ and over 65 within walking distance of this population.

There are 39,361 people living in these two age groups in Konyaaltı. Individuals in this age group are generally unable to go to health centers on their own by driving or using public transport. Therefore, the population experiencing distress is approximately $20.0 \%$ of the total population in the two age groups. Although there are major problems in building accessibility, accessibility is better in terms of rate and quantity compared to the population. The main reason for this situation is that the majority of the buildings within the areas accessible to FHCs contain more population than the buildings outside the accessible areas. Although population accessibility can be provided to a greater extent compared to buildings, it is not at a sufficient level.

A substantial number of people live outside the accessible area in the research area. Traveling long distances in access to family health centers by elderly individuals causes problems, and patients either prefer transportation by vehicle or go to hospitals even for simple procedures. It is observed that the population between the ages of 0-4 and 5-9 has low rates of access to FHCs. It is obvious that problems will arise when it is considered that younger children walk to FHCs with their relatives, and those who cannot walk move to FHCs. In order to prevent the problem, new FHCs should be built in suitable areas in the aforementioned neighborhoods. 
Table 3. Distribution of the population aged 0-9 and over 65 by neighborhoods

\begin{tabular}{|c|c|c|c|c|}
\hline \multirow{2}{*}{ Neighbourhood } & \multirow{2}{*}{ Population } & \multicolumn{2}{|c|}{$\mathrm{AGE}$} & \multirow{2}{*}{ Total } \\
\hline & & $0-9$ & $65+$ & \\
\hline Akdamlar & 419 & 50 & 37 & 87 \\
\hline Akkuyu & 3,477 & 416 & 308 & 724 \\
\hline Altınkum & 8,503 & 1,017 & 753 & 1,770 \\
\hline Arapsuyu & 6,969 & 834 & 617 & 1,451 \\
\hline Aşağıkaraman & 1,540 & 184 & 136 & 321 \\
\hline Aydınlık & 979 & 117 & 87 & 204 \\
\hline Baht1l1 & 1263 & 151 & 112 & 263 \\
\hline Çağlarca & 283 & 34 & 25 & 59 \\
\hline Çakırlar & 1257 & 150 & 111 & 262 \\
\hline Çamlıbel & 495 & 59 & 44 & 103 \\
\hline Çitdibi & 117 & 14 & 10 & 24 \\
\hline Dağ & 537 & 64 & 48 & 112 \\
\hline Demircilik & 226 & 27 & 20 & 47 \\
\hline Doyran & 648 & 78 & 57 & 135 \\
\hline Geyikbayırı & 542 & 65 & 48 & 113 \\
\hline Gökçam & 462 & 55 & 41 & 96 \\
\hline Gökdere & 86 & 10 & 8 & 18 \\
\hline Gürsu & 14,355 & 1,717 & 1271 & 2,988 \\
\hline Hacisekililer & 552 & 66 & 49 & 115 \\
\hline Hisarçandır & 648 & 78 & 57 & 135 \\
\hline Hurma & 28,109 & 3,363 & 2489 & 5,852 \\
\hline Karatepe & 892 & 107 & 79 & 186 \\
\hline Kir & 589 & 70 & 52 & 123 \\
\hline Kuruçay & 130 & 16 & 12 & 27 \\
\hline Kuşkavağ1 & 3,169 & 379 & 281 & 660 \\
\hline Liman & 18,680 & 2,235 & 1654 & 3,889 \\
\hline Mollayusuf & 10,548 & 1,262 & 934 & 2,196 \\
\hline Öğretmenevleri & 8,921 & 1,067 & 790 & 1,857 \\
\hline Pınarbaşı & 14,916 & 1,785 & 1321 & 3,105 \\
\hline Sarısu & 6,750 & 808 & 598 & 1,405 \\
\hline Siteler & 16,771 & 2,006 & 1485 & 3,491 \\
\hline Suiçeçek & 388 & 46 & 34 & 81 \\
\hline Toros & 9,691 & 1,159 & 858 & 2,017 \\
\hline Uluç & 6,912 & 827 & 612 & 1,439 \\
\hline Uncalı & 18,013 & 2,155 & 1595 & 3,750 \\
\hline Üçoluk & 211 & 25 & 19 & 44 \\
\hline Yarbaşçandır & 410 & 49 & 36 & 85 \\
\hline Yeni & 358 & 43 & 32 & 75 \\
\hline Zümrüt & 262 & 31 & 23 & 55 \\
\hline Total & & 22,621 & 16,740 & 39,361 \\
\hline
\end{tabular}

\section{References}

Akdamar E. 2017. The role of big data in reaching the smart city ideal. Kent Academy, 10(30), 200-215.

Albino V, Berardi U, Dangelico RM. 2015. Smart cities: Definitions, dimensions, performance, and initiatives. Journal of urban technology, 22(1), 3-21.

Çelikyay HH. 2013. Transformation from Technology Vortex to Smart City: The Case of Istanbul. Bursa: II. Turkish Postgraduate Studies Congress - Proceedings Book V 6-8 May 2013, Bursa

Deniz M. 2018. Analysis Of Accessibility Of Family Health Centers In Uşak With Gis. Electronic Turkish Studies, 13(26), 475-791

Deniz M, Kocaman E, Topuz M. 2018. Analysis of the location of family health centers (FHC) in Turgutlu district in terms of accessibility with GIS - In the proceedings of TÜCAUM 30th Year International Geography Symposium (pp. 704-712). Ankara: Turkish Geography Research and Application Center.
Deniz M, Kazdal K, Topuz M. 2020. An Example for the Analysis of Accessibility to Family Health Centers with GIS: The City of Rize. Journal of Atatürk University Institute of Social Sciences, 24(3), 1407-1422.

Deniz M, Kocaman E, Topuz M. 2021. Analysis of Accessibility to Family Health Centers in Salihli City with GIS. Electronic Turkish Studies, 16(1), pp:187-201.

Duman N, İrcan MR. 2020. Analysis of accessibility to schools in Karaköprü on the basis of geographic information systems (GIS). International Journal of Geography and Geography Education (IGGE), (42), 543-566.

Güray E, Kemeç S. 2016. Spatial accessibility analysis of preprimary, primary and secondary schools in the Van metropolitan area (582-588) [Conference paper]. $6^{\text {th }}$ Remote Sensing- GIS Symposium (UZAL - CBS 2016), Adana, Turkey.

Kwan VL., Tran TP. 2021. Health Infrastructure Accessibility in San Joaquin, CA. In Partial Fulfillment of the Requirements for the Degree Bachelor of Science, City and Regional Planning, $50 \mathrm{p}$. 
Melo ECAD, Figueiredo TRMD, Cardoso MAA, Paes NA. 2015. Accessibility of users with hypertension in the family health strategy. Escola Anna Nery, 19, 124-131.

Mendonça MM, Aleluia ÍRS, Sousa MLTD, Pereira M. 2021. Family Health Strategy Care Accessibility in West Bahia. Ciência \& Saúde Coletiva, 26, 1625-1636

Ministry of Environment and Urbanization. 2014. Spatial Plans Production Regulation, Official Gazette Publication Date 14.06.2014, Official Gazette Number: 29030

OpenStreetMap katılımciları. 2021 <https://download.geofabrik.de/europe/turkey.html\#>. 22 Ağustos 2021.

TUİK. 2020. Population statistics https://data.tuik.gov.tr/ (accessed on 01.09.2021).
Yasak U. 2020. Evolotion of accessbility to educational institutions in citiy of Kula by network analysis. V. Krystev, M. S. Dinu, R. Efe, E. Atasoy (Ed.), Advances in Social Science Research, (324-357). St. Kliment Ohridski Universty Press

Yeșil M., Yesil P. 2017. The Investigation of the Accessibility of Children's Playgrounds in the Town of Ordu. Turkish Journal of Agriculture-Food Science and Technology, 5(9), 10241030.

Yomralioglu T. 2005. Overview of Municipalities' KBS/GIS Applications in Turkey, Invited Paper, YvKB'06Construction and Informatics in the City Congress, 8-9 June, pp.173-180, Ankara, ISBN 9944-5291-0-9 